\title{
Pathogenesis of oedema in chronic severe anaemia: studies of body water and sodium, renal function, haemodynamic variables, and plasma
} hormones

Inder S Anand, Y Chandrashekhar, Roberto Ferrari, Philip A Poole-Wilson, Peter C Harris

\begin{abstract}
Background-Patients with chronic severe anaemia often retain salt and water. Fluid retention in these patients is not caused by heart failure and the exact mechanisms remain unclear. This study was designed to examine some of the possible mechanisms.

Methods and results-Haemodynamic variables, body fluid compartments, renal function, and plasma hormones were measured in four patients with oedema caused by chronic severe anaemia (mean (SE) haematocrit 13 $(1 \cdot 7))$ who had never received any treatment. Cardiac output was increased (6.1 $(0.6) 1 / \mathrm{min} / \mathrm{m}^{2}$ ) and right atrial $(7.8$ (1) mm $\mathrm{Hg})$, mean pulmonary arterial (20.5 (2.0) $\mathrm{mm} \mathrm{Hg}$ ), and mean pulmonary arterial wedge $(13(2 \cdot 7) \mathrm{mm}$ Hg) pressures were slightly increased. The mean systemic arterial pressure (81 (1.3) $\mathrm{mm} \mathrm{Hg})$ and systemic vascular resistance (12.3 (1.1) $\mathrm{mm} \mathrm{Hg} \times \mathrm{min} \times \mathrm{m}^{2} / 1$ were low. There were significant increases in total body water $(+14 \%)$, extracellular volume $(+32 \%)$, plasma volume $(+70 \%)$, and total body exchangeable sodium $(+30 \%)$. Renal blood flow was moderately decreased $(-46 \%)$ and the glomerular filtration rate was slightly reduced $(-24 \%)$. There were significant increases in plasma noradrenaline $(2 \cdot 1-$ fold $)$, renin activity (15-fold), aldosterone (3-2-fold), growth hormone (6.3-fold), and atrial natriuretic peptide (12-fold).
\end{abstract}

Conclusion-In patients with oedema caused by chronic severe anaemia there is retention of salt and water, reduction of renal blood flow and glomerular filtration rate, and neurohormonal activation similar to that seen in patients with oedema caused by myocardial disease. However, unlike patients with myocardial disease, patients with anaemia have a high cardiac output and a low systemic vascular resistance and blood pressure. It is suggested that the low concentration of haemoglobin in patients with anaemia causes a reduced inhibition of basal endothelium-derived relaxing factor activity and leads to generalised vasodilatation. The consequent low blood pressure may be the stimulus for neuro- hormonal activation and salt and water retention.

(Br Heart f 1993;70:357-362)

Chronic severe anaemia is often associated with various degrees of salt and water retention. ${ }^{1-3}$ When fluid retention is severe the condition is often referred to as "congestive heart failure". ${ }^{3}$ Though the pathogenesis of salt and water retention in congestive heart failure caused by low output states has been well studied, ${ }^{45}$ the mechanisms of fluid retention in patients with chronic severe anaemia remain unclear. Patients with anaemia and "congestive heart failure" have a high cardiac output which increases with exercise even more than in healthy subjects. ${ }^{12}$ The intracardiac filling pressures of these patients are usually normal or only slightly raised ${ }^{267}$ and myocardial contractility is normal or increased. ${ }^{8}$ All the haemodynamic changes are rapidly reversed after the anaemia is corrected. ${ }^{1267}$ Because there is little evidence that myocardial dysfunction is a cause of salt and water retention in chronic severe anaemia, it has been suggested that a better term for the condition is a "non-cardiac congestive state". 9 Few detailed physiological studies have been made in patients with chronic severe anaemia and fluid retention. ${ }^{238}$ The mechanism of salt and water retention has remained elusive because it is rare to find such patients who have not received treatment for "congestive heart failure", which itself may affect the mechanisms being studied. ${ }^{1011}$

We present data on haemodynamic variables, body fluid compartments, renal function, and plasma hormones in four untreated patients with oedema caused by chronic severe anaemia and compare the results with those found in patients with untreated congestive heart failure caused by myocardial disease.

\section{Patients and methods}

PATIENTS

The studies were carried out at the Postgraduate Institute of Medical Education and Research, Chandigarh, India, on four patients (one man and three women) admitted with chronic severe anaemia (haematocrit 9-16\%) who had had symptoms for 2 to 4 
months (mean (SE) 2.9 (0.8) months). They complained of fatigue and shortness of breath (mean New York Heart Association class, $2 \cdot 7$ $(0 \cdot 2))$. All looked pale and had mild to moderate ankle oedema and one (A2) had mild ascites. The jugular venous pressure was raised $(6(1 \cdot 5) \mathrm{cm})$ and the liver was enlarged to an average (SD) of $5.7(0.5) \mathrm{cm}$ below the right costal margin. No patients had lymph node or splenic enlargement. A chest radiograph showed a slightly increased cardiothoracic ratio $(0.52(0.02))$ but no signs of pulmonary venous congestion. The electrocardiogram showed non-specific ST segment and $T$ wave changes. The cause of anaemia was severe iron deficiency caused by chronic hookworm infection in two (A1 and A2), dietary iron deficiency in one (A3), and chronic bleeding haemorrhoids in one (A4). Routine clinical chemistry, serum creatinine, liver function tests and in particular serum albumin were normal. None of the patients had been treated for anaemia or "congestive heart failure". They were on a normal diet and salt was not restricted. Sodium balance was not studied.

\section{PROTOCOL}

The studies were performed after we obtained written, informed consent from the patients and the study was approved by the local ethics committee. Patients were studied on two consecutive days. Hormones and haemodynamic variables were measured on the first day and body fluid compartments and renal blood flow measurements on the second day. Two patients (A1 and A2) were restudied after anaemia had improved with treatment.

\section{HAEMODYNAMIC VARIABLES}

Haemodynamic measurements were made in the postabsorptive state with a Swan-Ganz thermodilution balloon catheter placed in the pulmonary artery. Arterial pressure was measured by cannulation of the left brachial artery with a 3F Teflon catheter (Seldicath). Pressures were measured with HewlettPackard 1290C transducers and a HewlettPackard 78354A monitor. The cardiac output was determined by thermodilution (Model SP 1445 Gould, Cleveland, Ohio). ${ }^{4}$

\section{WATER AND SODIUM SPACES AND RENAL FUNCTION}

Body water, sodium spaces, and renal function were measured by standard isotope dilution techniques. ${ }^{412}$ Briefly, plasma volume was calculated from the volume of distribution of $5 \mathrm{mCi}{ }^{125}$ I-labelled human serum albumin 10 minutes after intravenous injection. The extracellular volume and glomerular filtration rate were measured simultaneously with $100 \mathrm{mCi}{ }^{51} \mathrm{Cr}$-labelled ethylenediaminetetraacetic acid (EDTA) and calculated by numerical analysis. Effective renal plasma flow (ERPF) was estimated with $100 \mathrm{mCi}$ ${ }^{125}$ I-labelled sodium iodohippurate (Hippuran) and also calculated by numerical analysis. This method of measuring ERPF is indepen- dent of assumed volumes of distribution and, therefore, particularly useful when oedema is present. Renal blood flow was calculated from ERPF and the haematocrit was corrected for trapped plasma. Total body water was determined with $100 \mathrm{mCi}$ tritiated water and total body exchangeable sodium with 20 $\mathrm{mCi}^{22} \mathrm{Na}$ administered orally. A specially designed protocol allowed all measurements to be made in one 24 hour period. ${ }^{412}$

\section{PLASMA HORMONES}

Plasma hormones were assayed in a $20 \mathrm{ml}$ blood sample drawn from a forearm vein after the patients had been recumbent for $30 \mathrm{~min}$ utes. The techniques are described in detail elsewhere. ${ }^{413}$ Plasma noradrenaline and adrenaline were measured by high-performance liquid chromatography with electrochemical detection. Plasma renin activity, aldosterone, vasopressin, cortisol, growth hormone, and atrial natriuretic peptide (ANP) were measured by radioimmunoassay.

\section{STATISTICAL ANALYSIS}

The data are presented as mean (SEM). The significance of the difference between various variables in patients with anaemia, controls, and patients with congestive heart failure was estimated with the unpaired Student's $t$ test.

\section{Results}

Tables 1-3 give the haemodynamic, body compartment, renal function, and plasma hormone data. Earlier data from healthy individuals and from patients with oedema caused by myocardial disease, obtained by identical methods, ${ }^{4}$ are also provided for comparison.

\section{HAEMODYNAMIC VARIABLES}

The resting heart rate was slightly increased $(\mathrm{p}<0.01)$ (table 1). The cardiac index was increased in all the patients, the average $(6 \cdot 13$ $(0.56)$ being $150 \%$ above normal $(p<0.01)$. The mean pulmonary arterial and wedge pressures were raised in one patient (A2) but were within the normal range in the others. Right atrial pressure was slightly raised in three and was even higher in one (A2). The mean systemic blood pressure was significantly reduced $(p<0.01)$. The most impressive finding was considerable reduction in the systemic vascular resistance $(p<0.01)$. Arterial blood gases were normal.

\section{BODY FLUID COMPARTMENTS AND RENAI} FUNCTION

All body fluid compartments were increased (table 2). Total body water was, on average, $14 \%$ greater than normal and the increase was accommodated almost entirely in the extracellular space. Total body water increased by $77 \mathrm{ml} / \mathrm{kg}$ and the extracellular space by $72 \mathrm{ml} / \mathrm{kg}$. The increase in extracellular space was divided between the extravascular and intravascular compartments but not in proportion to their normal volumes: the plasma volume increased by a much greater 
Table 1 Haemodynamic variables and arterial blood gases in patients with oedema caused by chronic severe anaemia, in controls, and in patients with oedema caused by myocardial disease

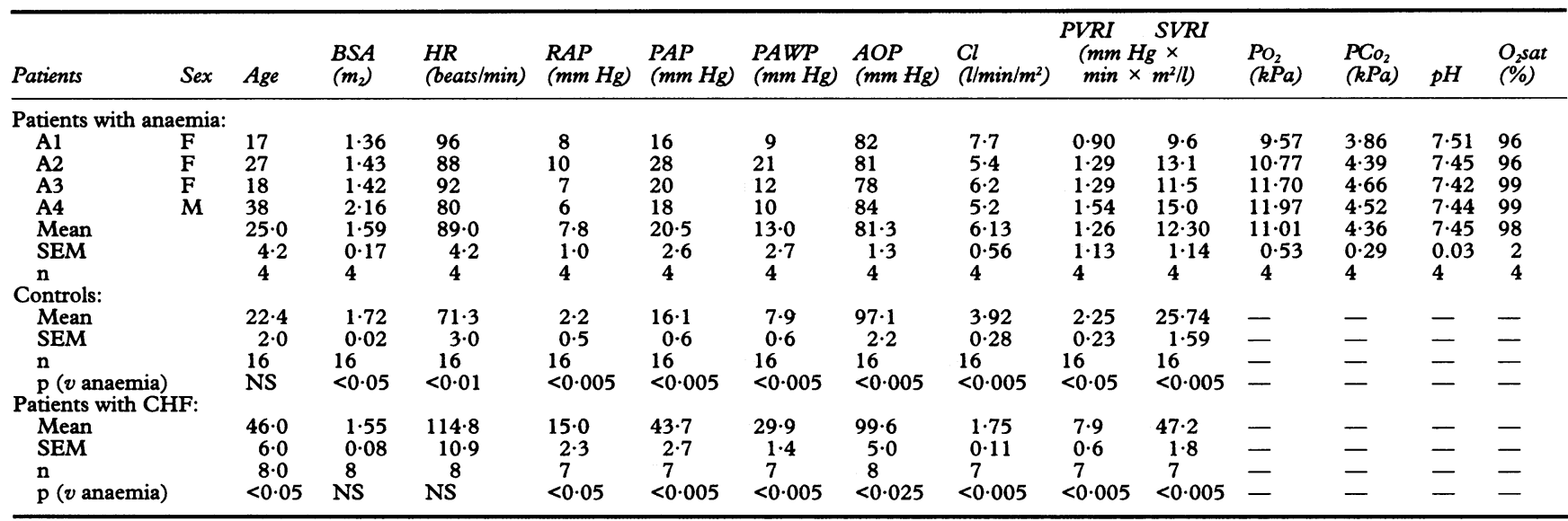

BSA, body surface area; HR, heart rate; RAP, mean right atrial pressure; PAP, mean pulmonary arterial pressure; PAWP, mean pulmonary arterial wedge pressure; AOP, mean systemic arterial pressure; CI, cardiac index; PVRI, pulmonary vascular resistance; (PAP-PAWP)/CI; SVRI, systemic vascular resistance (AOPRAP)/CI; CHF, congestive heart failure (data from reference 4). Data on controls come from reference 19.

amount $(70 \%)$ than the increase of $32 \%$ in the extracellular space. The increase in blood volume was, however, not significant because the haematocrit had decreased by nearly $70 \%$. The total body exchangeable sodium was $30 \%$ above normal. The effective renal plasma flow was nearly $22 \%$ below normal but the calculated renal blood flow was reduced by a much greater amount (46\%) because of the decreased haematocrit.

PLASMA HORMONES

The plasma concentration of noradrenaline was increased in every patient, with the average being more than twice normal $(p<0.01)$ (table 3). Plasma adrenaline was, however,

Table 2 Water volumes and renal function in patients with oedema caused by chronic severe anaemia, in controls, and in patients with oedema caused by myocardial disease

\begin{tabular}{|c|c|c|c|c|c|c|c|c|c|}
\hline Patients & $\begin{array}{l}P V \\
(\mathrm{ml} / \mathrm{kg})\end{array}$ & $\begin{array}{l}P C V \\
(\%)\end{array}$ & $\begin{array}{l}B V \\
(m l / k g)\end{array}$ & $\begin{array}{l}E C V \\
(\mathrm{ml} / \mathrm{kg})\end{array}$ & $G F R$ & $\underset{\left(\mathrm{ml} / \mathrm{min} / 1 \cdot 73 \mathrm{~m}^{2}\right)}{E R P F}$ & $E R B F$ & $\begin{array}{l}\text { TBNaE } \\
\text { (mmol/kg) }\end{array}$ & $\begin{array}{l}T B W \\
(\mathrm{ml} / \mathrm{kg})\end{array}$ \\
\hline $\begin{array}{l}\text { Patients with anaemia: } \\
\text { A1 } \\
\text { A2 } \\
\text { A3 } \\
\text { A4 } \\
\text { Mean } \\
\text { SEM } \\
\text { n }\end{array}$ & $\begin{array}{c}64 \cdot 5 \\
98 \cdot 0 \\
72 \cdot 6 \\
57 \cdot 7 \\
73 \cdot 2 \\
7 \cdot 6 \\
4\end{array}$ & $\begin{array}{c}16 \\
9 \\
11 \\
16 \\
13 \cdot 0 \\
1 \cdot 7 \\
4\end{array}$ & $\begin{array}{r}74 \cdot 9 \\
106 \cdot 2 \\
80 \cdot 2 \\
66.9 \\
82 \cdot 1 \\
7 \cdot 4 \\
4\end{array}$ & $\begin{array}{c}277 \\
372 \\
294 \\
254 \\
299 \cdot 3 \\
22 \cdot 2 \\
4\end{array}$ & $\begin{array}{c}78 \\
58 \\
76 \\
89 \\
75 \cdot 0 \\
5 \cdot 7 \\
4\end{array}$ & $\begin{array}{c}398 \\
265 \\
354 \\
481 \\
374 \cdot 4 \\
39 \cdot 0 \\
4\end{array}$ & $\begin{array}{r}462 \\
287 \\
391 \\
558 \\
425 \\
57 \\
4\end{array}$ & $\begin{array}{c}52 \cdot 9 \\
63 \cdot 2 \\
60 \cdot 7 \\
56 \cdot 1 \\
58 \cdot 2 \\
2 \cdot 3 \\
4\end{array}$ & $\begin{array}{c}586 \\
690 \\
608 \\
569 \\
613 \cdot 3 \\
23 \cdot 1 \\
4\end{array}$ \\
\hline $\begin{array}{l}\text { Controls: } \\
\text { Mean } \\
\text { SEM } \\
\text { n } \\
\text { p ( }(v \text { anaemia })\end{array}$ & $\begin{array}{l}43 \\
3 \\
11 \\
<0.005\end{array}$ & $\begin{array}{l}45 \cdot 6 \\
1.3 \\
7 \\
<0 \cdot 001\end{array}$ & $\begin{array}{l}71 \cdot 6 \\
5 \cdot 7 \\
11 \\
\text { NS }\end{array}$ & $\begin{array}{c}227 \\
13 \\
11 \\
<0.01\end{array}$ & $\begin{array}{l}99 \\
3 \\
9 \\
<0.005\end{array}$ & $\begin{array}{c}479 \\
19 \\
11 \\
<0.01\end{array}$ & $\begin{array}{c}792 \\
32 \\
11 \\
<0.005\end{array}$ & $\begin{array}{l}44.7 \\
1.9 \\
10 \\
<0.005\end{array}$ & $\begin{array}{c}536 \\
20 \\
9 \\
<0.025\end{array}$ \\
\hline $\begin{array}{l}\text { Patients with CHF: } \\
\text { Mean } \\
\text { SEM } \\
\text { n } \\
\text { p ( } v \text { anaemia })\end{array}$ & $\begin{array}{c}58 \\
3 \\
6 \\
<0.05\end{array}$ & $\begin{array}{l}39.3 \\
1.6 \\
6 \\
<0.001\end{array}$ & $\begin{array}{c}87 \cdot 7 \\
4 \cdot 0 \\
7 \\
\text { NS }\end{array}$ & $\begin{array}{r}301 \\
24 \\
6 \\
\text { NS }\end{array}$ & $\begin{array}{r}65 \\
8 \\
6 \\
\text { NS }\end{array}$ & $\begin{array}{c}140 \\
25 \\
6 \\
<0.005\end{array}$ & $\begin{array}{c}211 \\
39 \\
6 \\
<0.01\end{array}$ & $\begin{array}{r}61 \\
3 \\
8 \\
\text { NS }\end{array}$ & $\begin{array}{r}623 \\
24 \\
7 \\
\text { NS }\end{array}$ \\
\hline
\end{tabular}

PV, plasma volume; PCV, packed cell volume; BV, blood volume; ECV, extracellular volume; GFR, glomerular filtration rate; ERPF, effective renal plasma flow; ERBF, effective renal blood flow; TBNaE, total body exchangeable sodium; TBW, total body water. Congestive heart failure and normal data are from reference 4.

Table 3 Plasma hormones in patients with oedema caused by chronic severe anaemia, in controls, and in patients with oedema caused by myocardial disease

\begin{tabular}{|c|c|c|c|c|c|c|c|c|}
\hline Patients & $\begin{array}{l}\text { Adrenaline } \\
(\mathrm{pg} / \mathrm{ml})\end{array}$ & $\begin{array}{l}\text { Noradrenaline } \\
(\mathrm{pg} / \mathrm{ml})\end{array}$ & $\begin{array}{l}\text { Renin } \\
\text { activity } \\
(\text { ng/ml } \times h)\end{array}$ & $\begin{array}{l}\text { Aldosterone } \\
(\mathrm{pg} / \mathrm{ml})\end{array}$ & $\begin{array}{l}A N P \\
(p g / m l)\end{array}$ & $\begin{array}{l}\text { Vasopressin } \\
(\mathrm{ng} / \mathrm{ml})\end{array}$ & $\begin{array}{l}\text { Growth } \\
\text { hormone } \\
\text { (ng/ml) }\end{array}$ & $\begin{array}{l}\text { Cortisol } \\
\text { (ng/ml) }\end{array}$ \\
\hline \multicolumn{9}{|c|}{ Patients with anaemia: } \\
\hline A1 & 36 & 319 & $16 \cdot 0$ & 85 & 61 & $23 \cdot 2$ & $2 \cdot 9$ & 230 \\
\hline A2 & 36 & 578 & 3.8 & 46 & 402 & 13.9 & $5 \cdot 8$ & 10 \\
\hline A3 & 121 & 919 & $12 \cdot 3$ & 229 & 442 & $9 \cdot 3$ & $8 \cdot 7$ & 15 \\
\hline A4 & 60 & 532 & $4 \cdot 8$ & 301 & 148 & $6 \cdot 6$ & $0 \cdot 2$ & 8 \\
\hline Mean & 63 & 587 & $9 \cdot 2$ & 165 & 263 & $13 \cdot 3$ & $4 \cdot \overline{4}$ & 66 \\
\hline SEM & 17 & 108 & $2 \cdot 6$ & 52 & 81 & $3 \cdot 2$ & 1.6 & 47 \\
\hline n & 4 & 4 & 4 & 4 & 4 & 4 & 4 & 4 \\
\hline \multicolumn{9}{|l|}{ Controls: } \\
\hline Mean & 84 & 275 & 0.60 & 52 & 22 & $7 \cdot 6$ & $0 \cdot 7$ & 74 \\
\hline SEM & 16 & 33 & $0 \cdot 10$ & 7 & 5 & $1 \cdot 1$ & $0 \cdot 2$ & 8 \\
\hline $\mathrm{n}$ & 15 & 16 & 16 & 16 & 16 & 15 & 16 & 16 \\
\hline $\mathrm{p}(v$ anaemia $)$ & NS & $<0.005$ & $<0.005$ & $<0.005$ & $<0.005$ & $<0.025$ & $<0.005$ & NS \\
\hline \multicolumn{9}{|l|}{ Patients with CHF: } \\
\hline Mean & 94 & 1719 & $5 \cdot 2$ & 330 & 314 & $5 \cdot 5$ & $8 \cdot 4$ & 129 \\
\hline SEM & 20 & 887 & $2 \cdot 0$ & 122 & 84 & $3 \cdot 1$ & $2 \cdot 2$ & 13 \\
\hline $\mathrm{n}$ & 7 & 7 & 8 & 7 & 6 & 7 & 8 & 8 \\
\hline $\mathrm{p}(v$ anaemia $)$ & NS & NS & NS & NS & NS & NS & NS & NS \\
\hline
\end{tabular}

ANP, atrial natriuretic peptide. Data on congestive heart failure and normal data come from reference 4 . 
Table 4 Haemodynamic variables, body fuid compartments, renal function, and plasma hormones in two patients before and after treatment

\begin{tabular}{|c|c|c|}
\hline & $\begin{array}{l}\text { Before treatment } \\
\text { (mean) }\end{array}$ & $\begin{array}{l}\text { After treatment } \\
\text { (mean) }\end{array}$ \\
\hline \multicolumn{3}{|l|}{ Haemodynamic variable: } \\
\hline Heart rate (beats/min) & 92 & 74 \\
\hline Right atrial pressure (mm Hg) & 9 & 4 \\
\hline Mean pulmonary artery pressure $(\mathrm{mm} \mathrm{Hg})$ & 22 & 15 \\
\hline Mean pulmonary wedge pressure (mm $\mathrm{Hg})$ & 15 & 8 \\
\hline Mean arterial pressure (mm Hg) & 82 & 104 \\
\hline Cardiac index $\left(1 / \mathrm{min} \times \mathrm{m}^{2}\right)$ & $6 \cdot 6$ & 3.9 \\
\hline \multicolumn{3}{|l|}{ Pulmonary vascular resistance } \\
\hline \multicolumn{3}{|l|}{ Systemic vascular resistance } \\
\hline$\left(\mathrm{mm} \mathrm{Hg} \times \min \times \mathrm{m}^{2} / \mathrm{l}\right)$ & $11 \cdot 4$ & $25 \cdot 7$ \\
\hline \multicolumn{3}{|l|}{ Body fluid compartment and renal function: } \\
\hline Extracellular volume $(\mathrm{ml} / \mathrm{kg})$ & 325 & 243 \\
\hline Plasma volume $(\mathrm{ml} / \mathrm{mg})$ & $81 \cdot 3$ & $61 \cdot 1$ \\
\hline Packed cell volume (\%) & $12 \cdot 5$ & 39.0 \\
\hline Blood volume $(\mathrm{ml} / \mathrm{kg})$ & 90. & $92 \cdot 1$ \\
\hline Total body water $(\mathrm{ml} / \mathrm{kg})$ & $638 \cdot 0$ & $588 \cdot 0$ \\
\hline Total body exchangeable sodium (mmol/kg) & $58 \cdot 1$ & $51 \cdot 6$ \\
\hline Glomerular filtration rate $\left(\mathrm{ml} / \mathrm{min} \times 1.73 \mathrm{~m}^{2}\right)$ & 68 & 154 \\
\hline Effective renal plasma flow $\left(\mathrm{ml} / \mathrm{min} \times 1.73 \mathrm{~m}^{2}\right)$ & 332 & 790 \\
\hline Effective renal blood flow $\left(\mathrm{ml} / \mathrm{min} \times 1.73 \mathrm{~m}^{2}\right)$ & 375 & 1184 \\
\hline \multicolumn{3}{|l|}{ Hormones: } \\
\hline Adrenaline (pg/ml) & 36 & 108 \\
\hline Noradrenaline $(\mathrm{pg} / \mathrm{ml})$ & 449 & 324 \\
\hline Plasma renin activity $(\mathrm{ng} / \mathrm{ml} \times \mathrm{h})$ & 9.9 & 0.6 \\
\hline Aldosterone (pg/ml) & 66 & 30 \\
\hline Vasopressin $(\mathrm{pg} / \mathrm{ml})$ & $18 \cdot 6$ & $9 \cdot 0$ \\
\hline Atrial natriuretic peptide (pg/ml) & 120 & 10 \\
\hline Growth hormone (ng/ml) & $4 \cdot 4$ & $2 \cdot 3$ \\
\hline Cortisol (ng/ml) & 232 & 50 \\
\hline
\end{tabular}

within the normal range. Renin activity was also increased in every patient; the mean value was 15 times normal. Serum aldosterone was raised in three patients but normal in one. Plasma ANP was raised in every patient and the mean was nearly 12 times normal. Growth hormone was raised in three and normal in one. Cortisol concentrations were variable.

EFFECT OF TREATMENT

All patients improved with treatment but only two (A1 and A2) could be reinvestigated: one patient (A4) was lost to follow up and the other (A3) did not wish to be restudied. All patients were given blood transfusions and iron supplements. None was treated with diuretics or cardiovascular drugs. Table 4 shows the results in the two patients. Both patients became symptom free and lost weight and oedema: patient A2 became free of ascites. The haemodynamic variables returned to normal. In particular, the blood pressure and systemic vascular resistance increased to normal values as the haematocrit improved. Clinical improvement and a reduction in oedema was associated with a substantial decrease in extracellular volume, total body water, and total body exchangeable sodium and an increase in effective renal plasma and blood flow and glomerular filtration rate. Though the plasma volume fell considerably, the blood volume did not change because the haematocrit increased from $12 \cdot 5$ to $39 \%$. The plasma hormones returned to normal values.

\section{Discussion}

We investigated patients with chronic severe anaemia and oedema who had never been treated. They had retained substantial quanti- ties of sodium and water (nearly 4.01 of excess water and $748 \mathrm{mmol}$ sodium). Despite a high cardiac output and a reduced systemic vascular resistance, the renal blood flow was reduced to nearly $50 \%$ of normal. The glomerular filtration rate was relatively preserved, averaging $75 \%$ of normal, suggesting greater vasoconstriction of the efferent renal arterioles than the afferent ones. The reduction in renal function that we saw in our patients has been described elsewhere. ${ }^{314} 15$ Renal blood flow falls in proportion to the severity of anaemia, and patients with severe anaemia and massive oedema have lower renal blood flows and higher renal vascular resistance than patients with lesser degrees of oedema. $^{3}$

The hormonal response consisted of an increase in plasma noradrenaline; activation of the renin-angiotensin-aldosterone system; and an increase in atrial natriuretic peptide, vasopressin, and growth hormone. There are almost no reported data on the neuroendocrine response of patients with chronic severe anaemia. Wassermann et al found high resting plasma noradrenaline concentrations in anaemic dogs and an exaggerated response to moderate exercise. ${ }^{16}$ Iron deficiency causes an increased excretion of urinary catecholamines in humans ${ }^{17}$ and in rats which is corrected by treatment. ${ }^{18}$ The increases in noradrenaline, renin, and aldosterone probably reflect a reflex response to the reduced blood pressure and decreased renal blood flow. The high concentration of ANP is surprising in view of the rather modest increase in filling pressures. Though plasma osmolality was not measured, the normal serum sodium indicates that it is likely to have been normal. Therefore the most likely cause of the increase in vasopressin is a non-osmotic release. An increase in growth hormone has never been reported in anaemia and is similar to that reported by us in other syndromes of salt and water retention. ${ }^{4519}$

MECHANISM OF REDUCED SYSTEMIC VASCULAR RESISTANCE IN CHRONIC SEVERE ANAEMIA

Measurement of the haemodynamic variables confirmed the presence of increased cardiac output; low arterial blood pressure; much reduced systemic vascular resistance; and mildly raised right atrial, pulmonary arterial, and wedge pressures shown previously in such patients. ${ }^{267}$ The mechanisms that lead to a low systemic vascular resistance in patients with chronic severe anaemia are not known but vasodilatation and low blood viscosity have been implicated. ${ }^{620} 21$ Viscosity, however, does not fully explain the low systemic vascular resistance. ${ }^{2021} \mathrm{We}$ have previously postulated ${ }^{22}$ that enhanced activity of endothelium-derived relaxing factor (EDRF) may be responsible for the vasodilatation seen in patients with chronic severe anaemia. Haemoglobin is an important inhibitor of EDRF. ${ }^{23} 24$ It binds avidly to nitric oxide and regulates the activity of EDRF. ${ }^{23-26}$ Infusion of stroma-free haemoglobin as replacement in haemorrhagic shock is associated with an 
immediate and pronounced increase in systemic vascular resistance that persists as long as haemoglobin remains in circulation..$^{27}{ }^{28} \mathrm{It}$ is, therefore, possible that low concentrations of haemoglobin in patients with chronic severe anaemia increase basal EDRF activity, leading to generalised vasodilatation and to the hyperdynamic circulatory state characteristic of chronic severe anaemia. The resulting increase in blood flow could further amplify the flow mediated release of EDRF. ${ }^{29-31}$ An increase in EDRF activity is responsible for the hyperdynamic circulation in patients with cirrhosis of liver, ${ }^{32} 33$ and for hypotension in patients with septic shock. ${ }^{34}$

COMPARISON OF FINDINGS IN CHRONIC SEVERE ANAEMIA WITH THOSE IN PATIENTS WITH OEDEMA FROM MYOCARDIAL DISEASE

The congestive state seen occasionally in patients with chronic severe anaemia is similar to that seen in patients with oedema caused by myocardial disease, but the mechanisms of salt and water retention in the two conditions may be different. We therefore compared the findings in patients with chronic severe anaemia with those, reported by us previously in patients with oedema from myocardial disease ${ }^{4}$ (tables 1-3).

The haemodynamic variables in these two conditions were entirely different (table 1). While the right-sided pressures were much raised in patients with myocardial disease, they were either normal or only slightly increased in patients with chronic severe anaemia. The most striking difference was seen in the systemic circulation. The cardiac output was considerably reduced in congestive heart failure but was increased in chronic severe anaemia. Also, while patients with congestive heart failure were able to maintain a normal arterial blood pressure by a considerable increase in the systemic vascular resistance, patients with chronic severe anaemia could not maintain a normal blood pressure because of systemic vasodilatation. The increase in cardiac output in anaemia was largely the result of an increase in the stroke volume with only a modest increase in heart rate, suggesting normal myocardial function. The hormone response was similar in both conditions. Thus despite increased sympathetic stimulation and activation of the reninangiotensin-aldosterone system, patients with oedema from chronic severe anaemia had markedly reduced systemic vascular resistance.

Despite the striking differences in the haemodynamic variables in these two conditions, the changes in the body fluid compartments and renal function were similar. The renal plasma and blood flow and glomerular filtration rate were reduced in both conditions, though the decrease was greater in patients with congestive heart failure. The systemic vascular resistance fell to nearly half normal in patients with anaemia, while it increased by $80 \%$ in patients with congestive heart failure. Despite this the renal vascular resistance increased in both conditions: by more than $40 \%$ in anaemia and more than $200 \%$ in congestive heart failure. It is, therefore, clear that patients with chronic severe anaemia constrict their renal vasculature while they have an overall systemic vasodilatation.

\section{PATHOPHYSIOLOGY OF SALT AND WATER} RETENTION IN CHRONIC SEVERE ANAEMIA The neurohormonal response, changes in renal circulation, and degree of salt and water retention in patients with oedema from chronic severe anaemia are qualitatively similar to those in patients with oedema from myocardial disease, conditions with fundamentally different haemodynamic mechanisms. We have previously shown that a similar pathophysiology is seen in patients with oedema from chronic obstructive pulmonary disease who, like patients with oedema from chronic severe anaemia, have reduced systemic vascular resistance. ${ }^{9}$ The common factor in all these conditions seems to be a tendency towards a low arterial blood pressure. Blood pressure is "threatened" in congestive heart failure by low cardiac output and in chronic severe anaemia and chronic cor pulmonale by decreased systemic vascular resistance. Low or "threatened" blood pressure evokes a reflex increase in sympathetic activity through the baroreceptors and activates the renin-angiotensin-aldosterone system through the juxtaglomerular cells, in the same way as do low cardiac output states. ${ }^{45}$ The increased sympathetic-stimulation reduces the renal blood flow and to a lesser extent the glomerular filtration rate and may contribute to the non-osmotic release of vasopressin. The net result is salt and water retention. The activated renin angiotensinaldosterone axis and vasopressin further help to retain salt and water. The extracellular volume expands and leads to release of ANP whose vasodilator properties may be expected to reduce the systemic vascular resistance further. Replacement of the red blood cells restores haemoglobin concentrations, inhibits EDRF activity, and reverses the process that contributed to salt and water retention. This sequence of events is consistent with the hypothesis ${ }^{35}$ that the syndrome of congestive heart failure is the result of sustained attempts to maintain arterial blood pressure by neurohormonal activation.

\section{LIMITATIONS OF THIS STUDY}

This study was carried out on only four patients. The major objective was to investigate patients with chronic severe anaemia who had salt and water retention and who had never been treated. Treatment, especially with diuretics has such profound effects on the neurohormones that it becomes difficult to distinguish between the effects of treatment and those of the disease itself. ${ }^{1011}$ However, it is difficult to find such patients in hospital practice and during a period of nearly 18 months only four such patients who had not received any diuretic treatment were admitted to a large teaching hospital. 
This study was supported by the Indian Council of Medical Research, British Heart Foundation, and EEC contract NST 2J-0071-1-i.

1 Varat MA, Adolph RJ, Fowler NO. The cardiovascular effects of anaemia. Am Heart $\mathcal{F}$ 1972;83:415-24.

2 Graettinger JS, Parsons RL, Campbell JA. A correlation of clinical and haemodynamic studies in patients with mild and severe anaemia with and without congestive heart failure. Ann Intern Med 1963;58:617-26.

3 Singhvi LM, Sharma VS, Mansharamani G. Mechanism of oedema in chronic severe anaemia. Br Heart $\mathrm{F}$ 1963; 25:89-96.

4 Anand IS, Ferrari R, Kalra GS, Wahi PL, Poole-Wilson PA, Harris P. Oedema of cardiac origin: Studies of body water \& sodium, renal function, haemodynamics and plasma hormones in untreated congestive heart failure. Circulation 1989;80:299-305.

5 Anand IS, Ferrari R, Kalra GS, Wahi PL, Poole-Wilson PA, Harris P. Pathogenesis of oedema in constrictive pericarditis. Studies of body water \& sodium, renal function, haemodynamics and plasma hormones before and after pericardiectomy. Circulation 1991;83:1880-7.

6 Duke M, Abelman WH. The haemodynamic response to chronic anaemia. Circulation 1969;39:503-13.

7 Roy SB, Bhatia ML, Mathur VS, Virmani S. Haemodynamic effects of chronic severe anaemia. Circulation 1963;28:346-56.

8 Florenzano F, Diaz G, Regonesi C, Escobar E. Left ventricular function in chronic anaemia: evidence of noncatecholamine, positive inotropic factor in serum. $\mathrm{Am} \mathcal{f}$ Cardiol 1984;54:638-45.

9 Echina LV. Circulatory congestion and heart failure. Circulation 1960;22:864-86.

10 Bayliss J, Norell M, Canepa-Anson R, Sutton G, PooleWilson $P$. Untreated heart failure: Clinical and neuroendocrine effects of introducing diuretics. $\mathrm{Br} \mathrm{Heart} f$ 1987;57:17-22.

11 Kubo SH, Clark M, Laragh JH, Borer JS, Cody RJ Identification of normal neurohormonal activity in mild congestive heart failure and the stimulating effect of congestive heart failure and the stimulating effect of
upright posture and diuretics. Am $₹$ Cardiol 1987;60: upright

12 Anand IS, Veal NB, Kalra GS, Ferrari R, Sutton G Lipkin D, Harris $P$, Poole-Wilson PA. Treatment of heart failure with diuretics: Body compartments, renal functions, and plasma hormones. Eur Heart $f 1989$; 10:445-50.

13 Ferrari R, Ceconi C, Signorini C, Anand IS, Harris P, Albertini A. Sample treatment for long distance air transport of human plasma for hormone assay. Clin Chem 1989;35:331-2.

14 Bradley SE, Bradley GP. Renal function during chronic anaemia in man. Blood 1947;2:192-202.

15 Renbi RD, Vorberger C, Keller HM. The renal excretion of sodium paraaminohippurate in anaemic subjects before and after red cell transfusion. Clin Sci 1962;23. 213-9.

16 Wassermann DH, Lavina H, Likely A, Vranic M. Effect of haematocrit reduction on hormonal and metabolic response to exercise. $7 \mathrm{Appl}$ Physiol 1985;58:1257-61.

17 Wagner A, Fortier N, Giroux A, Lukes J, Snyder LM Catecholamines in adult iron deficient patients. Experentia 1979;35:681-2.

18 Vorrhess LM, Stuart MJ, Stockman SA, Oski FA. Iron deficiency anaemia and increase in urinary norepinephrine. Pediatrics 1975;86:542-7.
19 Anand IS, Chandrashekhar Y, Ferrari $R$, Sarma $P$ Guleria R, Jindal SK, Wahi PL, Poole-Wilson PA Harris P. Pathogenesis of congestive state in chronic obstructive pulmonary disease. Studies of body water obstructive pulmonary disease. Studies of body water
and sodium, renal function, haemodynamics and plasma hormones during oedema and after recovery. Circulation 1992;86:12-21.

20 Fowler NO, Holmes JC. Blood viscosity and cardiac output in acute experimental anaemia. $\mathcal{F}$ Appl Physiol 1975;39:453-6.

21 Escobar E, Jones NL, Rapaport E, Murray JF. Ventricular performance in acute normovolemic anaemia and
effects of beta blockade. Am $\Im$ Physiol 1966;211:877-84.

22 Anand IS, Chandrashekhar $Y$. Reduced inhibition of endothelial-derived relaxing factor causes the hyperdynamic circulation in chronic severe anaemia. Medical Hypotheses 1993 (in press)

23 Martin W, Smith JA, White DG. The mechanisms by which haemoglobin inhibits the relaxation of rabbit aorta induced by nitrovasodilators, nitric oxide, or bovine retractor penis inhibitory factor. $\mathrm{Br} \mathcal{F}$ Pharmacol 1986;89:563-71.

24 Martin W, Villani GM, Jothianandan D, Furchgott RF Selective blockade of endothelium-dependent and glyceryl trinitrate-induced relaxation by haemoglobin and by methylene blue in the rabbit aorta. F Pharmacol Exp Ther 1985;232:708-16.

25 Gibson QH, Roughton FJW. The kinetics and equilibria of the reactions of nitric oxide with sheep haemoglobin. of the reactions of nitric

26 Murad F, Mittal CK, Arnold WP, Katsuki S, Kimura H. Guanylate cyclase: activation by azide, nitro compounds, nitric oxide and hydroxyl radical and inhibition by haemoglobin and myoglobin. Adv Cyclic Nucleotide Res 1978;9:145-58.

27 Nees JE, Hauser CJ, Shippy C, State D, Shoemaker WC. Comparison of the cardiorespiratory effects of crystallised haemoglobin, whole blood, albumin and ringer lactate in the resuscitation of shock in dogs. Surgery 1978;83:639-47.

28 Hauser CJ, Shoemaker WC. Haemoglobin solutions in the treatment of haemorrhagic shock. Crit Care Med 1982. 10:283-7.

29 Pohl U, Busse R, Kuon E, Bassenge E. Pulsatile perfusion stimulates the release endothelial autacoids. $f A p p$ Cardiol 1986;1:215-35.

30 Lamontagne D, Pohl U, Busse R. Mechanical deformation of vessel wall and shear stress determine basa release of endothelial derived relaxing factor in the intact rabbit coronary vascular bed. Circ Res 1992;70: 123-30.

31 Miller VM, Vanhoutte PM. Enhanced release of endothelium derived factor(s) by chronic increases in blood flow. Am ₹ Physiol 1988;255:H446-51.

32 Vallance $P$, Moncada S. Hypothesis: induction of nitric oxide synthase in the vasculature underlines the hyperoxide synthase in the vasculature underlines the hyper-

33 Pizcueta P, Pique JM, Bosch J, Whittle BJR, Moncada S Effects of endogenous nitric oxide inhibition on the haemodynamic changes of portal hypertensive rats [abstr]. Gastroenterology 1991;100:785.

34 Kilbourn RG, Gross SS, Jurbran A, Adams J, Griffith $O W$, Levi $R$, Lodato $R F$. $N^{\mathrm{G}}$-methyl-L-arginine inhibits tumor necrosis factor-induced hypotension: implication for the involvement of nitric oxide. Proc Natl Acad Sci USA 1990;87:3639-2.

35 Harris P. Role of arterial pressure in the oedema of heart disease. Lancet 1988;i:1036-8. 